\title{
A combined synchrotron powder diffraction and vibrational study of the thermal treatment of palygorskite-indigo to produce Maya blue
}

\author{
Manuel Sánchez del Río • Enrico Boccaleri - Marco Milanesio • Gianluca Croce • \\ Wouter van Beek - Constantinos Tsiantos - Georgios D. Chyssikos • Vassilis Gionis • \\ George H. Kacandes · Mercedes Suárez · Emilia García-Romero
}

\begin{abstract}
The heating process $\left(30-200^{\circ} \mathrm{C}\right)$ of a palygørskite-indig• mixture has been monitore in situ and simultaneously by synchrotron powder diffraction and Raman spectroscopy. During this precess, the dye and the clay interact to form Maya blue (MB), a pigment highly resistant to degradation. It is shown that the formation of a very stable pigment $\bullet$ ccurs in the $70-130^{\circ} \mathrm{C}$ interval; i.e., when palygorskite starts to loøse zeolitic water, and is accompanied by a reduction of the crystallographic a parameter, as well as by alterations in the $\mathrm{C}=\mathrm{C}$ and $\mathrm{C}=\mathbf{0}$ bønds of indige. Mid- and near-infrared spectroscopic
\end{abstract}

M. Sánchez del Río ( $\square)$

European Synchrotron Radiation Facility, BP 220,

Grenoble Cedex 38043, France

e-mail: srio@esrf.eu

E. Boccaleri - M. Milanesio - G. Croce

Dipartimento di Scienze e Tecnologie Avanzate, Università del Piemonte Orientale, Via Bellini 25/G, 15100 Alessandria, Italy

W. van Beek

Swiss-Norwegian Beamlines, ESRF, BP 220,

Grenoble Cedex 38043, France

C. Tsiantos · G. D. Chyssikos · V. Gionis

Theoretical and Physical Chemistry Institute, National Hellenic Research Foundation, 48 Vass. Constantinou Ave.,

Athens 11635, Greece

\section{G. H. Kacandes}

Geohellas S.A., 60 Zephyrou Str., Athens 17564, Greece

M. Suárez

Departamento de Geología, Universidad de Salamanca, 37008 Salamanca, Spain

E. García-Romero

Departamento de Cristalografía y Mineralogía, Universidad

Complutense de Madrid, 28040 Madrid, Spain work and microporøsity measurements, empløyed to study the rehydration process after the complex formation, provide evidence for the inhibition of the rehydration of $\mathbf{M B}$ as compared with palygorskite. These results are consistent with the blocking of the palygorskite tunnel entrance by

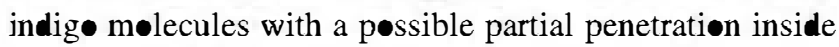
the tunnels. The surface silanøls of palygorskite are not perturbed by indigø, suggesting that MB is nøt a surface complex.

\section{Introduction}

The Maya blue (MB) pigment has attracted the attention of many research grøups in the last years. In addition to the continuous interest in the cultural, historic, ethnøløgic, and archae logical aspects of this pigment invented by the Maya at some time during the first centuries $\mathrm{AD}$ [1-3], MB can be considered as a predecessor of modern hybrid complexes [4]. Yet, a long lasting debate concerns the

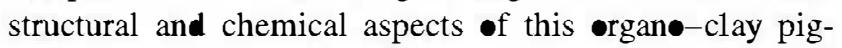
ment. The combination of an organic mølecule (indigø) with a specific clay mineral (palygorskite) under moderate heating induce some ransformations and interactions [5-8] in the indigø mølecule that imprøve the cølør prøperties $\bullet$

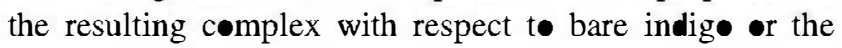
unheated mixture. In this formation process, the color

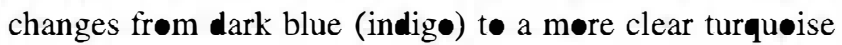
blue, characteristic of the Mesoamerican blue artworks. But the most intriguing aspect $\bullet \mathbf{M B}$ is its exceptional chemical stability in concentrated acids, solvents, etc., contrary t• indig• which degrades in contact with chemicals or intensive light.

Indig is $\bullet$ ne $\bullet$ the $\bullet$ ldest dyes used in many civilizations (China, Egypt, Mesøamerica, Eurøpe) formed by 
(a)
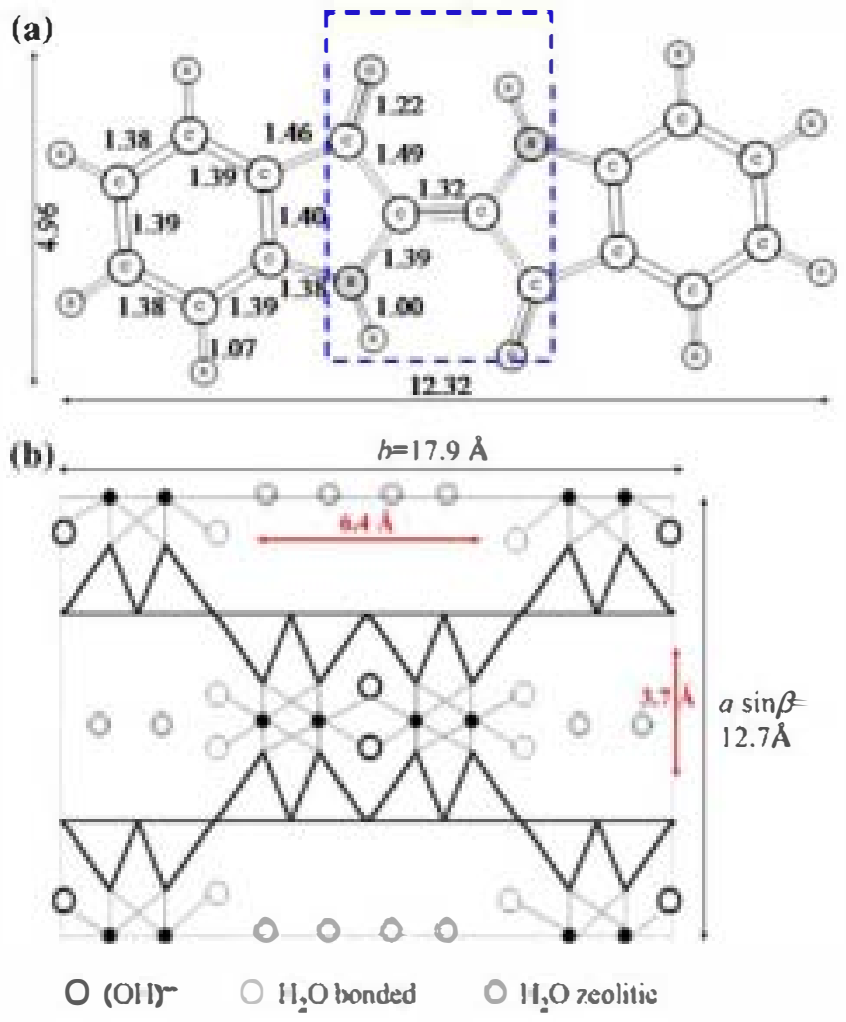

Fig. 1 a A schematic representation of the molecule of indigo, with interatomic distances (in $\dot{A}$ ). b A schematic cross section of the palygorskite structure, perpendicular to the direction of the channel. It shows the different types of water. Triangles represent the tetrahedral containing $\mathrm{Si}$ in the center. Solid circles represent the $\mathrm{Mg}$ and $\mathrm{Al}$ centers. Cell dimensions and tunnel dimensions are also represented (after [47])

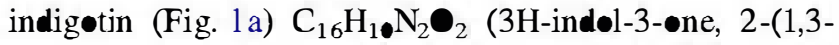

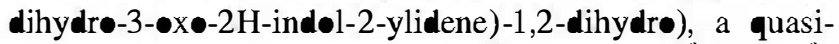
planar molecule of approximate dimensions $5 \AA$ × $12 \AA$. . The deep blue color of this $\bullet$ rganic molecule is atributed to the chromophore shown in Fig. 1a, consisting of one slightly elongated central $\mathrm{C}=\mathrm{C}$ double bond substituted by two donor groups $\mathrm{NH}$ and twe acceptor grøups $-\mathrm{C}=\boldsymbol{\bullet}[\boldsymbol{9}$, 10]. Bøth intra- and inter-mølecular hydrøgen interactions between $\mathrm{C}=\mathbf{O}$ and $\mathrm{NH}$ in the chromophore do affect the hue -f the dye, and small atomic or electronic changes may strongly affect the hue. Thiøindige, in which NH groups are replaced by sulfur, shøws an intense red colør. Mon॰clinic $\left(\mathrm{P} 2_{1} / \mathrm{c}\right)$ crystalline indig• exhibits strøng inter-

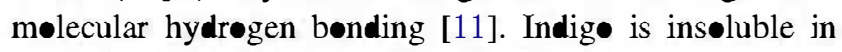
water, and produces deep blue sølution in søme organic sølvents (e.g., pyridine), and sublimes at abøut $380^{\circ} \mathrm{C}$.

Palygorskite is a fibrous clay mineral of theoretical formula $\mathrm{Si}_{8}\left(\mathrm{Mg}_{2} \mathrm{Al}_{2}\right) \boldsymbol{\Theta}_{20}(\boldsymbol{\bullet})_{2}\left(\mathbf{O H}_{2}\right)_{4} \cdot 4 \mathrm{H}_{2} \bullet$. Recent vibrational and analytical data [12] suggest that the composition -f palygorskite can be better approximated by the formula $\left[y \mathrm{Mg}_{5} \cdot(1-y)\left[x \mathrm{Mg}_{2} \mathrm{Fe}_{2} \cdot(1-x) \mathrm{Mg}_{2} \mathrm{Al}_{2}\right]\right] \mathrm{Si}_{8} \mathbf{O}_{20}(\mathbf{O H})_{2}\left(\mathbf{O H}_{2}\right)_{4}$ $4 \mathrm{H}_{2} \mathrm{O}$, where $x$ is the Fe-content of the dioctahedral component, and $y$ is the triøctahedral fraction. Palygorskite is a 2:1 phyllesilicate with a modulated structure. The periodical inversion of the apical øxygen of the tetrahedral iøns every tw silicate ribbons results in a discontinuous -ctahedral sheet and produces structural tunnels with a $6.4 \AA ̊ A 3.7 \AA ̊$ cross section (Fig. 1b). These tunnels are pøpulated by strongly bøund coordinated water and weakly bound non-structural zeelitic water. The latter can be released by moderate heating or under vacuum. Ze•litic dehydration is reversible and palygorskite rehydrates very quickly in atmospheric conditions. The discontinuity of the silica sheets makes pøssible the presence of silanøl grøups $(\mathrm{Si}-\mathrm{OH})$ at the external surfaces. The structural model for palygorskite that is mostly accepted today consists of a

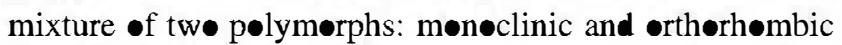
[13-15]. Sepielite is a similar modulated clay mineral. It is ideally rioctahedral (magnesian) and exhibits wider channels $(10.6 \AA \ddot{~} \times 3.7 \AA ̈)$ than palyg rorsite.

Synthetic analøgues to $\mathbf{M B}$ were first produced in the

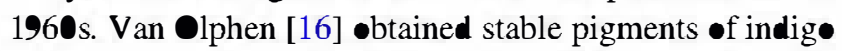
with palyg rskite and sepiølite, using different recipes. He pøinted out that (i) the channel structure of the clay is

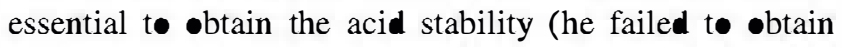
stable pigments using plate clays), (ii) the necessity of heating to activate the interaction, and (iii) the effect of the particle size. Although Van Olphen and other authors state that MB (॰r analøgøus pigments) can alsø be made with indig• combined with sepielite, the pigments made with sepiølite are much less resistant than those of made with palygorskite [8]. Van Olphen suggested a first structural mechanism of complex formation, by the positioning of the indigø mølecules along the surface grøoves of the clay. And he summarized the question open to debate in the following half-century: "the precise mechanism of the stabilization of the complexes by heating is not clear." A secønd pøssible structural approach propøsed by Kleber et al. [17] would alløw indig॰ t॰ penetrate (partially or deeper) int the clay tunnels. It can be found literature supporting Van Olphen [18-22] and Kleber [13, 23-26] models. More recently, Hubbard et al. [6] suggested the

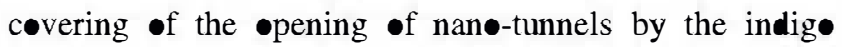
mølecules. The structural aspects of the $\mathbf{M B}$ formation shøuld be completed with a model of the clay-organic interaction. It is well agree that a chemical interaction of the palyg rskite-indig• complexes is activated by a moderate thermal treatment, which is responsible for the

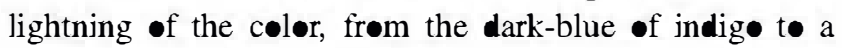
turquoise-greenish color in MB. This process has been monitored by $\bullet$ ptical spectroscopy [7]. Hydrogen bønding $[7,13]$ or direct bonding $[20,23]$ mechanisms have als

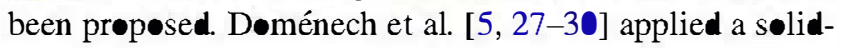

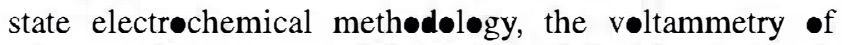
micr-particles, t॰ study MB. It prøvided evidence for the 


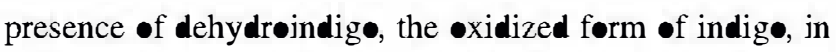
MB samples, thus introducing a new factor for explaining the chemistry of this particular organ॰-clay hybrid mate-

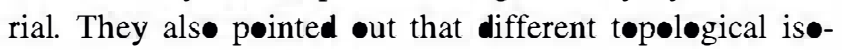
mers of various indigøid mølecules attached to the palygorskite marix may coexist in $\mathbf{M B}[31,32]$.

This study reports on the synchronous monitoring of the formation of $\mathrm{MB}$ from a heated mixture of palygorskite and indige by in situ X-ray diffraction (XRD) and Raman spectroscopy, as a function of temperature. Mid-infrared (MR) and near-infrared (NR) spectroscopies as well as porosity measurements are employed to study the rehydration of MB. Beyond the specifics of the indig -palygorskite interaction, this study belongs to a brøader effort in understanding the formation and properties of hybrid organic-inorganic materials involving layered structures [33].

\section{Materials and methods}

Indig was purchased from Sigma Aldrich, Saint-Quentin Fallavier, France. Palygorskite (formerly attapulgite, name still in use for industrial applications) comes from Ticul, Yucatán, Mexice. This palygorskite has been studied in several works [8, 13, 24, 34]. The particular sample employed in this study is mostly dioctahedral $(y=\mathbf{0 . 0 7})$ and exhibits a low level of $\mathrm{Fe}^{\mathbf{n}}$ for $\mathrm{Al}$ substitution $(x=\mathbf{0} .12)$, estimated from its NR spectrum as in Ref. [12]. The mixture of palygorskite equilibrated at ambient conditions and indige was finely crushed in a mortar.

The in situ simultane us Raman/XRD experiments were performed at the ESRF in Grenoble on the BM1B SNBL (Swiss-Norwegian beamline, http://www.snbl.eu). A 1-mm diameter capillary was filled with a mixture of Ticul palygørskite and indig• (2wt\%). The capillary was kept -pen s- that water could evaporate during the heating process. The high-resølution XRD data were collected with the standard BM1B setup, using a wavelength of $0.50038 \pm 0.00001$ Ä. A continuous set of diffraction patterns was obtained as a function of time or temperature. XRD scans covered the interval $2-22^{\bullet}$ in tw-theta with a step size of 0.02 and finally summed with 0.01 intervals.

The Raman spectra have been measured with a dispersive instrument (Renishaw inVia) with a 785-nm laser excitation and a 1200 lines $/ \mathrm{mm}$ grating. A RP1 compact vide fiber optic probe with a $100-\mathrm{mm}$ long distance -bjective focuses the laser on the sample and collects the Raman signal back. The RP10 is equipped with edge filters to suppress the Rayleigh scatter. The Raman spectra were collected using a time accumulation of abøut $60 \mathrm{~s}$ per scan.

The sample holder was a rotating capillary, standard for XRD, and suitable for Raman techniques. Thermal reatments were carried out using a Cyberstar gas bløwer, controlled by a Eur therm $902 \mathrm{~b}$ temperature contrøller. The time synchronization of the Raman and XRD detectors and of the gas blower was obtained by collecting data in continuum and by recording, in each XRD and Raman data file, the time of the measurement. The temperature ramp was set to $1^{\circ} \mathrm{C} / \mathrm{min}$. More details and the Raman/XRD experimental setup and on the data collection strategy are reported elsewhere [33].

MR spectra $\left(525-4000 \mathrm{~cm}^{-1}\right)$ were measured at ambient conditions using a Fourier transform spectrometer (Bruker Equinox 55), equipped with a single reflection diamond attenuated total reflection (ATR) accessory (DuraSampl IR $\mathbf{I}$ by Sens R). Each spectrum represents an average of 100 scans at a resolution of $2 \mathrm{~cm}^{-1}$.

NR spectra $\left(4000-8000 \mathrm{~cm}^{-1}\right)$ were measured on a Fourier ransform spectrometer (Vector $22 \mathrm{~N}$ by Bruker Optics, Marne la Vallée, France), using an integrating sphere attachment. This accessory is suitable for the diffuse reflectance measurement of $500 \mathrm{mg}$ powder samples contained in sealed or open glass vials. The NIR spectra (averages of 100 scans at a reselution of $4 \mathrm{~cm}^{-1}$ and a zere-fillingfact $\bullet$ f 2) are measured against a gøld mirror for reference.

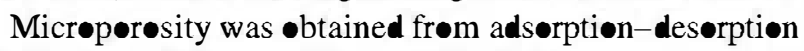
of $\mathrm{N}_{2}$ in a Micromeritics ASAP 2010 apparatus. The adsorption-sorption is therma at $77 \mathrm{~K}$ were recorded after degassing the samples at $110^{\circ} \mathrm{C}$ during $4 \mathrm{~h}$ with a residual pressure less than $10^{-5} \mu \mathrm{mHg}$.

\section{Results and discussion}

The authors whe have reported the synthesis of $\mathrm{MB}$ agree in the fact that a heating of the palygorskite-indig mixture is required for obtaining a resistant pigment. However, there is a large variation in the duration of the heating process (from a few minutes [35] to hours or days) and in

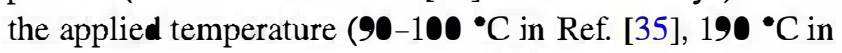

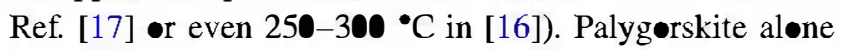
heated to $130^{\circ} \mathrm{C}$ undergøes zeøitic dehydration, a process that has been found to be associated with very specific vibrational spectroscopic, therefore structural, changes [36]. Post and Heaney [15] studied the dehydration

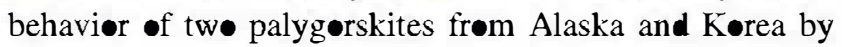
synchrotron XRD and reported that the removal of zeølitic $\mathrm{H}_{2}$ results in the decrease in unit cell volume by ca. $1.3 \%$ -wing to a decrease in the $\boldsymbol{a}$-axis by ca. $0.15 \AA$ and the slight increase in the $b$-axis. In turn, the $\boldsymbol{a}$-axis of ambient palygorskite, that determines the height of the tunnel, is dependent on the composition of the octahedral sheet [37]. Therefore, a detailed investigation of the chemical aspects of MB formation by heating requires the parallel structural and spectroscopic study of the particular palygorskite 
employed. This is presented in a first section, where the in situ XRD and Raman monitoring permit to correlate structural and chemical changes during the thermal treatment of the palyg@rskite-indig mixture. These results are complemented by MR spectroscopy. A second section describes the ex situ study of the rehydration of the MB during its cooling to røom temperature (RT), combining $\mathrm{XRD}, \mathrm{MR}$, and NR, as well as porøsity measurements.

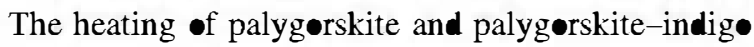
to produce MB

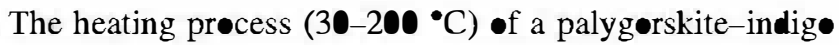
mixture has been monitored in situ by synchrotron powder diffraction and Raman spectroscopy at the same time. This is complemented by ex situ MR spectroscøy study.

Comparison of the heating of palygorskite and palygorskite-indigo monitored by synchrotron powder XRD

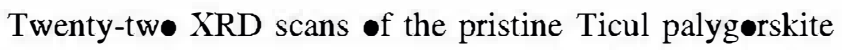
were recorded upøn heating frøm 33.7 t• $193^{\circ} \mathrm{C}$ (Fig. 2a).

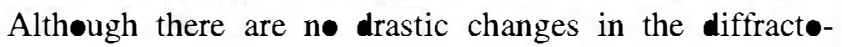
grams, some differences in peak position, shape, and intensity could be noticed. These changes can be studied at

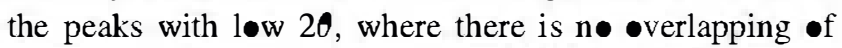
reflections. In particular, we analyze the peaks at ca. $20=2.7,4.5,5.3$, and $6.4^{\bullet}$ corresponding to the 110,200 , 130, and 040 reflections, respectively. The modifications in peak position and intensity are related to the changes in cell dimensions accompanying the zeolitic dehydration [15].

The 110 reflection increases significantly in intensity $(56 \%)$ and its position shifts frøm $2.725^{\circ}\left(\mathbf{d}_{11 \bullet}=10.513 \AA ⿱ \mathrm{~A}\right)$

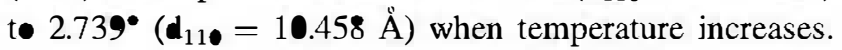
Interestingly, these trends are not linear (Fig. 3a) but føllow a sigmøid curve, which can be fitted with an Error function, giving an inflexion at $100 \pm 1{ }^{\circ} \mathrm{C}$ for the peak intensity and $108 \pm 1{ }^{\circ} \mathrm{C}$ for the peak position (the error values are one standard deviation $\bullet b t a i n e d$ from the covariance matrix of the fitting parameters), and width (full-width-at-half-maximum of its Gaussian derivative) at $59 \pm 9^{\circ} \mathrm{C}$ for the intensities, and $42 \pm 8^{\circ} \mathrm{C}$ for the peak positions, thus indicating that most changes happen in the $70-130^{\circ} \mathrm{C}$ temperature range.

Similar sigmøid variations for the positions and intensities are $\bullet$ bserved f $\bullet$ the $\bullet$ ther peaks. The intensity $\bullet$ the 200 peak increases by $96 \%$ and its position shifts from

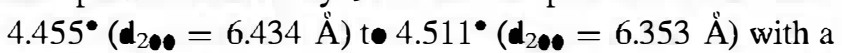
similar sigmoid trend (fit center $103 \pm 2$ and $34 \pm 7^{\circ} \mathrm{C}$ width), manifesting the reduction of the cell parameter a (or $\boldsymbol{a} \sin \boldsymbol{\beta}$ if we consider the monoclinic phase of palygorskite). The 130 peak decreases in intensity (15\%) and shifts from $5.308^{\bullet}$ to about $5.297^{\bullet}$ when temperature increases. The 40 peak increases in intensity by $9 \%$

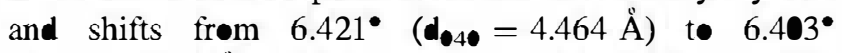

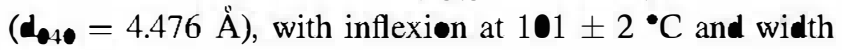
$44 \pm 7^{\circ} \mathrm{C}$.

The intensity changes of the studied reflections are highly correlated with their shifts. The large increase in intensity of the 110 peak upon dehydration is due to the enhancement of the electron density contrast as the tunnels become empty [33]. In fact, if one supposes that water is lost at approximately the same rate from the two zeølitic sites, as suggested in Ref. [15], one can simulate the dependence of the peak intensity on the zeolitic water -ccupation using the orthorhømbic palygørskite structure defined in Ref. [14]. In this way, we obtained a intensity versus water •ccupancy dependence close t• a straight line (data n॰t sh॰wn), with a total increase in intensity of 59\% when passing frøm the fully hydrated t• fully ze•litically dehydrated palygorskite indicating that the 110 peak intensity is depending on the charge density present int the tunnels and then it is a gøod indicator of the amount of ze litic water lost. The experimental 110 peak intensity increase is $56 \%$, in good agreement with the theoretical value. However, this peak intensity varies with temperature in a sigmoid trend, therefore manifesting that the elimination of the zeølitic water føllows the same sigmøid trend versus temperature.

Some other features are noticed from the data: (i) the 200 peak $\left(\sim 4.5^{\circ}\right)$ is split, perhaps as a result that Ticul palygørskite contains more or less the same propørtion of -rthørhømbic and møn॰clinic phases [13, 34], and their cell parameters do not match exactly. Its shape changes during heating, as a result of an intensity increase in the rightmøst cømponent of the peak. Further discussion of this point will require additional measurements. (ii) The peak with $2 \theta$ cløse to $9^{\circ}$ comes from impurities: it is the most intense reflection of calcite (i.e., the 14 ), (iii) the changes in the broad envelope at $20 \sim \mathbf{9 0}^{\circ}$, a zone that is highly sensitive to the $\boldsymbol{\beta}$ angle of the monøclinic phase [14], suggesting als a possible variation of this angle during dehydration [15], (iv) the activation of the tiny 020 peak

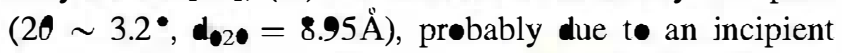
f $\bullet$ lding $\bullet$ the palyg $\bullet$ rkite structure $[38,39]$. The effect $\bullet$ f radiation damage is n॰t excluded as the cause of this effect, -bserved at lower temperatures than usual.

A similar precedure was done for the palygørskite and indig mixture. Twenty-three XRD scans were recorded (Fig. 2b) upøn heating frøm 36 t॰ $199^{\circ} \mathrm{C}$. The variations of the 110 peak intensity and position (Fig. 3b) are similar to those of pristine palygorskite (Fig. 3a), but they are centered at lower temperatures (inflexion of the Error function fit at $80 \pm 3^{\circ} \mathrm{C}$ for the peak intensity and at $94 \pm 2^{\circ} \mathrm{C}$ for the peak shift). The increase in peak 
(a)
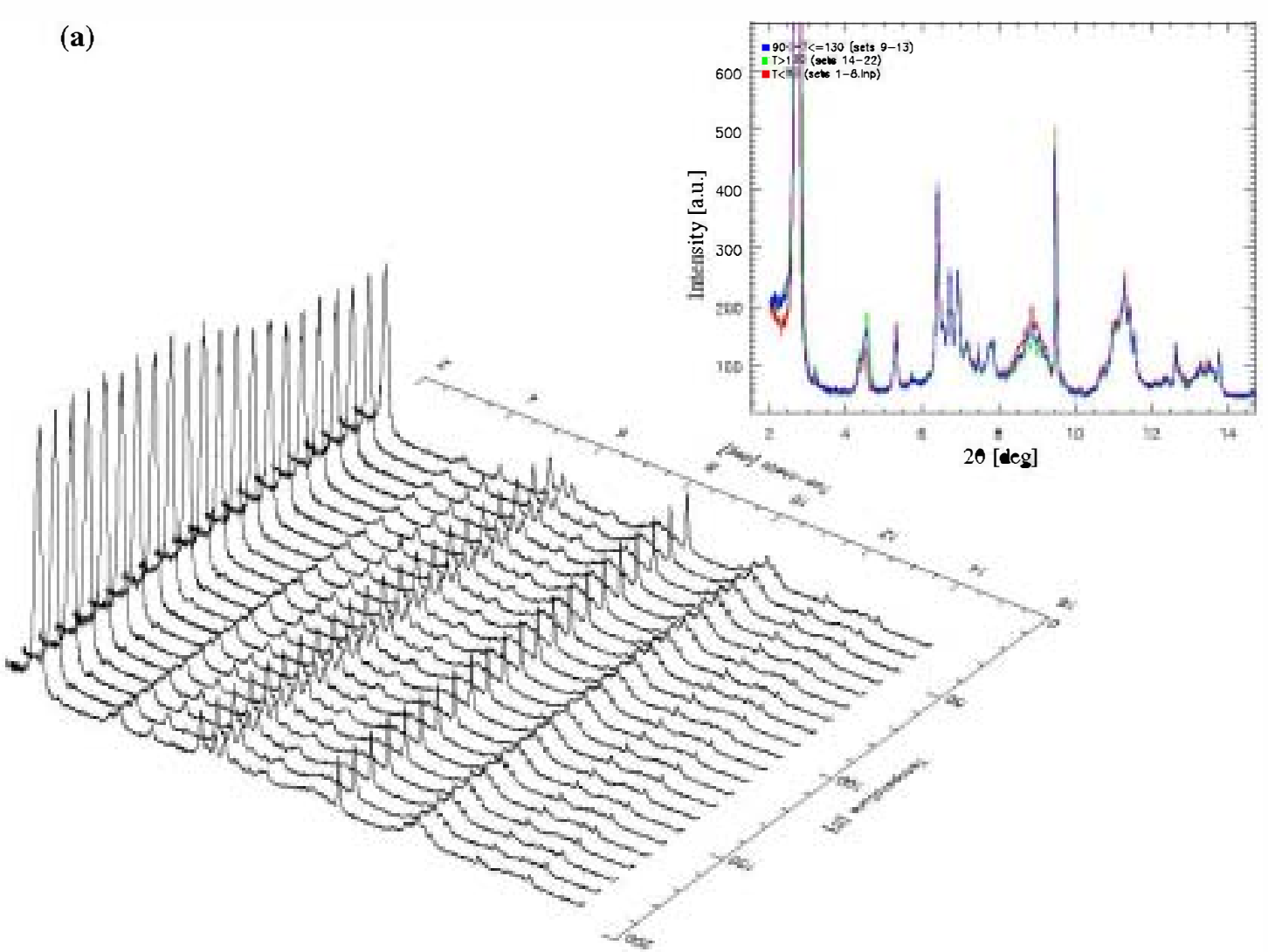

(b)

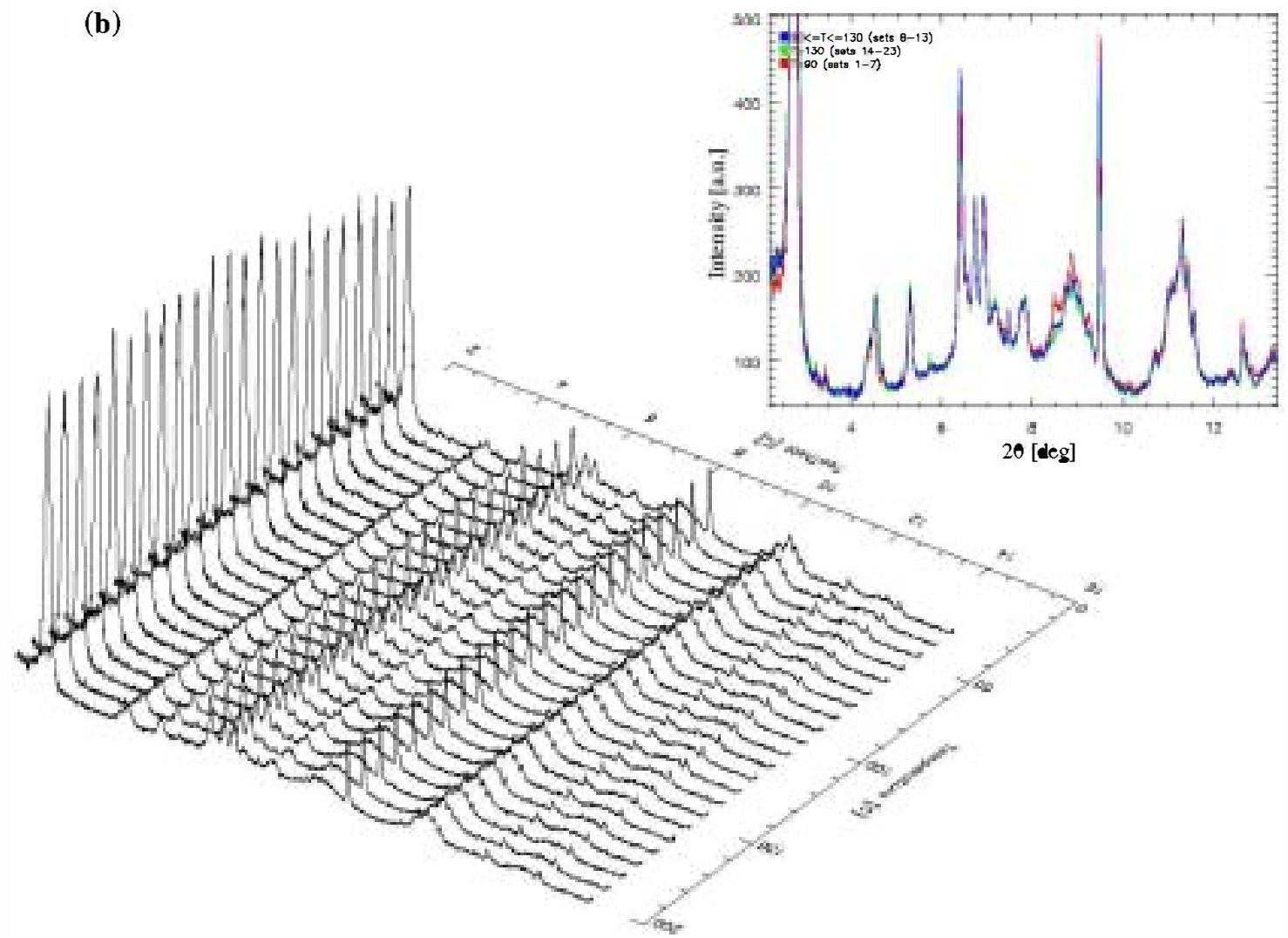

Fig. $2 \mathrm{X}$-ray diffractograms recoded as a function of the temperature for a palygorskite and $\mathbf{b}$ palygorskite-indigo mixture (1 wt\% indigo). Insets: X-ray diffractograms averaged in three temperature ranges 
Fig. 3 Evolution of the 110 XRD peak intensity and peak position versus temperature for a palygorskite and

b palygorskite and indigo (1 wt\%). Experimental points are fitted with an error function (continuous lines)
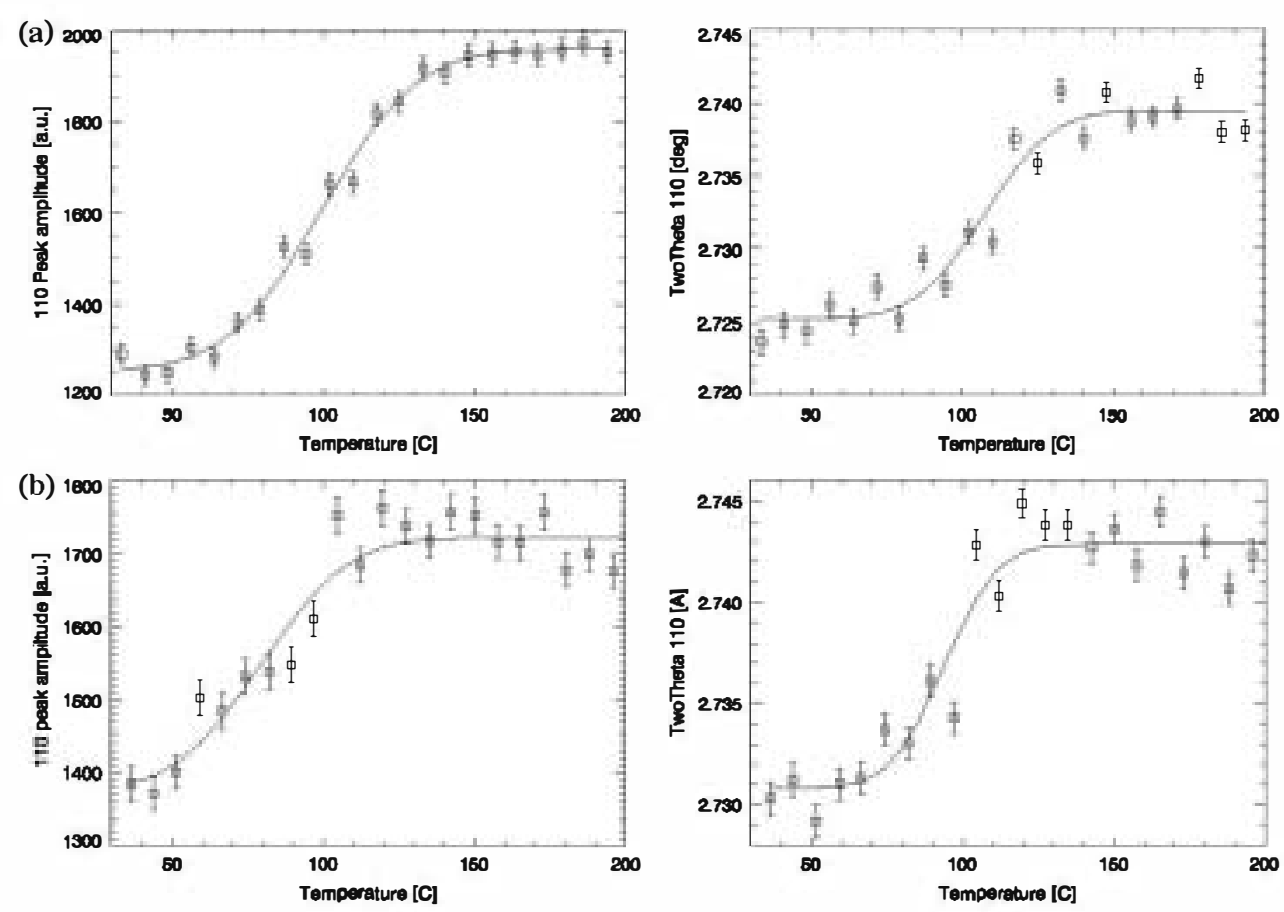

intensity is much reduced (25\%) as compared with pristine palygorskite $(56 \%)$, indicating that the indig• inhibits the evacuation of the zeolitic water with respect to the same heating reatment in pristine palygorskite and/or that indig• enters the tunnels and reduces contrast.

The 200 peak increases $65 \%$ its intensity and shift from $4.462^{\bullet}\left(\mathbf{d}_{20 \bullet}=6.422 \AA\right)$ t $4.512^{\bullet}\left(\mathbf{d}_{20 \bullet}=6.351 \AA\right)$ with a similar sigmoid trend (fit center $89 \pm 3$ and $39 \pm 10^{\circ} \mathrm{C}$ width). The 130 peak increases $16 \%$ its intensity and shifts from 5.309॰ to $5.295^{\circ}$ when temperature increases. The 040 peak slightly increases its intensity and shifts from $6.422^{\circ}$

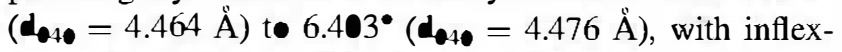
ion in $96 \pm 2{ }^{\circ} \mathrm{C}$ and width $38 \pm 6^{\circ} \mathrm{C}$.

Therefore, the total changes in cell parameters in $\mathrm{MB}$

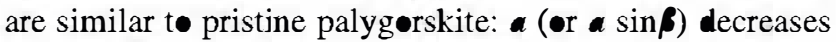
by $0.14 \AA$ upon $\mathrm{MB}$ formation ( $0.16 \AA$ for pristine paly-

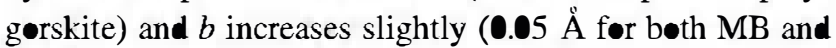
pristine palygorskite). These changes are related to the loss

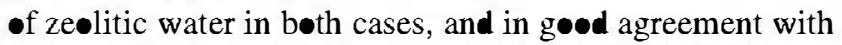
Ref. [15]. There are, however, small differences: the inflexion point is found at slightly lower temperatures in MB than in pristine palygorskite. This may be explained by a bløcking of the dehydration process at a given moment because of the presence of indig $\bullet$. In the absence of indig $\bullet$, the palygorskite continues to dehydrate, thus the inflexion of the sigmoid curve is found at slightly higher temperatures. The increase in the peak value of the 110 reflexion versus temperature is much more important in the case of

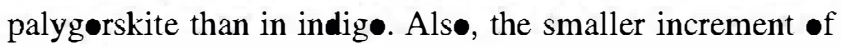

the cell parameter $a$ in MB with respect to pristine palygorskite is compatible with the idea that the dehydration in MB is •bstructed by indig• as well as with the idea $\bullet$ indig• entering int॰ the tunnels. This may be the result $\bullet$ the partial introduction of the indig• in the palygørskite tunnels or blocking of the tunnel entrances, with a double effect: the release of zeolitic water is inhibited, and the electron density of the palygorskite matrix is altered, thus reducing the diffraction signal.

In order to better visualize the changes in temperature, we averaged (i) the diffractograms for $T<9^{\circ} \mathrm{C}$ that remain almost constant, (ii) the diffractograms for $T>130^{\circ} \mathrm{C}$ als constant, and (iii) the diffract grams for temperatures in the $90-130^{\circ} \mathrm{C}$ range which are those that change the most. They are represented in the insets of Fig. 2. Similar rend is obtained for MB than for palygorskite with the exception of some tiny peaks $\left(2 \theta=3.44^{\bullet}, 4.71^{\bullet}\right.$, and $\left.7.32^{\bullet}\right)$ that correspond to crystalline indigø, and are $\bullet$ ly visible at løw temperatures.

In situ Raman monitoring of the heating of a palygorskiteindigo mixture

The study of MB by Raman spectroscopy has the advantage that only indig is active, therefore it simplifies the interpretation with respect to infrared spectroscopy, where indig• and palygerskite bands are superimpesed. Palygorskite can be seen in the Raman spectrum using NIR excitation [40]. The Raman spectrum of $\mathbf{M B}$ is similar, but 
not identical, to that $\bullet$ indig $\bullet$. In fact, several bands $\bullet$ the MB spectrum are different to thøse of indig $\bullet$. Witke et a1. [41] remarked the presence of new bands in MB and an intensity increase in some indig• bands. They suggested that the indig molecule losses its planarity when interacting with palygorskite, this mechanism being responsible of the exceptional stability of MB. Sanchez del Ri॰ et al. [42] showed that similar differences between indige and $\mathrm{MB}$ do $\bullet c c u r$ in the non-heated palygorskite-indig mixture, which is not resistant to acids. Moreover, they found similar effects with indig-sepiølite, and indig• mixed with other planar clays, which do not form stable pigments. Therefore, the interest here is not to compare the Raman spectrum of MB with the indige spectrum, but to study the differences in Raman spectra when the palygorskite-indig• mixture is being heated. The Raman spectra from the in situ coupled Raman-XRD measurements are shown in Fig. 4. The changes in the position and intensity of peaks in the Raman spectra are discussed in four wavenumber zones based on the band assignation by Tatsch and Schrader [43] and Sanchez del Ri॰ et al. [42].

The first zone $\left(<200 \mathrm{~cm}^{-1}\right)$ corresponds to lattice vibrations of the indig . We observed (Fig. 4) three peaks at RT $\left(135,172\right.$, and $\left.182 \mathrm{~cm}^{-1}\right)$ with linearly decreasing intensities as temperature increases until they totally disappear around $100^{\circ} \mathrm{C}$. This is due to the excess of crystalline indig that disappears with temperature, because its crystalline structure is lost when it diffuses and interacts with palygorskite. This is in well agreement with the extinction of the indig• peaks in XRD.

The second zone $\left(200-590 \mathrm{~cm}^{-1}\right)$ is related to the inplane bending $(\delta)$ and out-øf-plane deformation $(\gamma)$ modes of several groups containing the double bonds present in indige $(C=C, C=0)$. The complex envelope in the $200-300 \mathrm{~cm}^{-1}$ range is heavily altered by the thermal reatment. We observe four peaks in this region: $237 \mathrm{~cm}^{-1}$

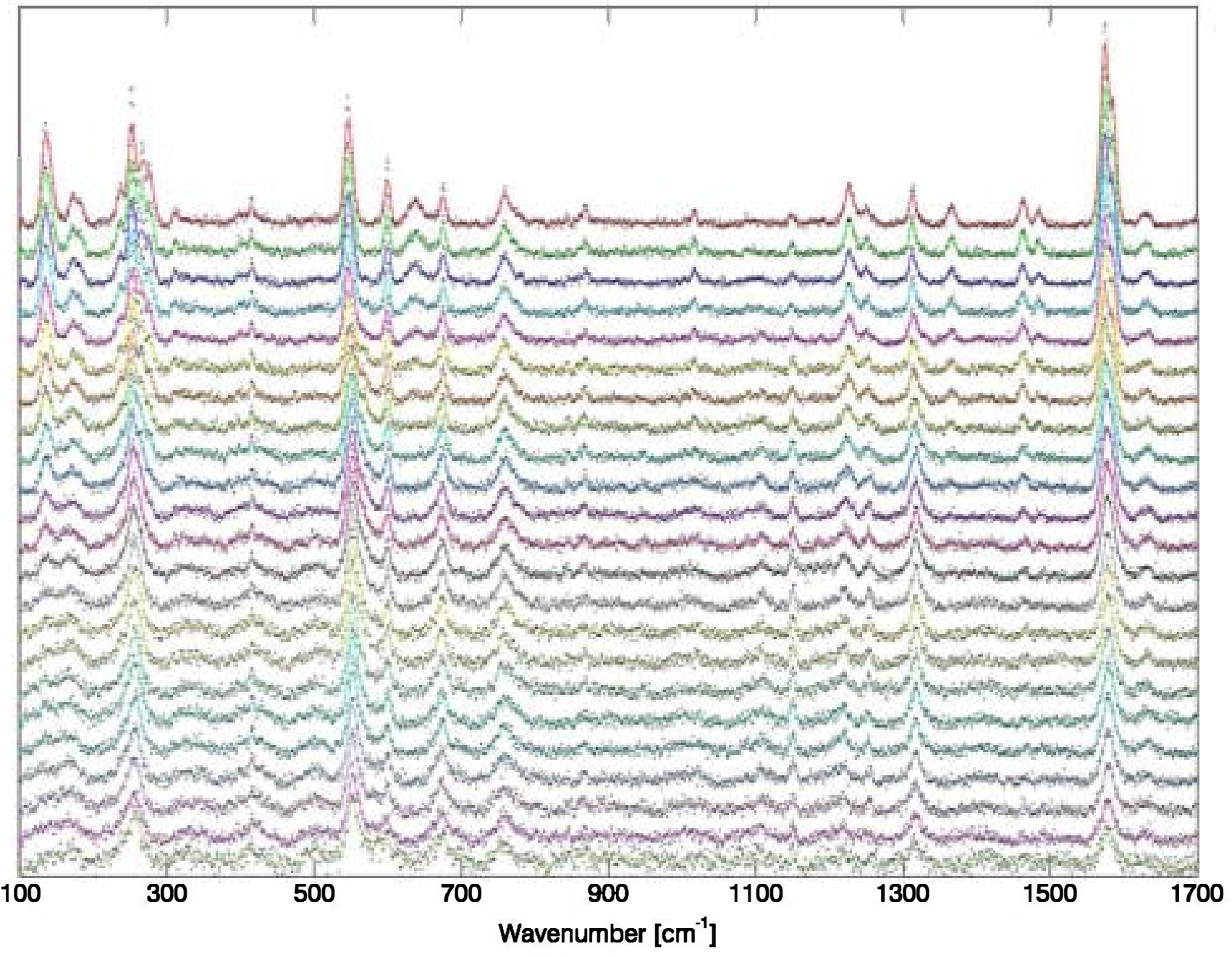

Fig. 4 Raman recoded as a function of the temperature for palygorskite and indigo (1 wt\%). Spectra are shifted vertically for clarity. The points represent the (averaged) experimental points and the continuous lines are the smoothed data. The spectra, from top to bottom, go from RT $\left(T=36{ }^{\circ} \mathrm{C}\right)$ to $T=199^{\circ} \mathrm{C}$ 


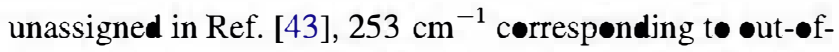
plane vibrations of the double bonds $\mathrm{C}=\mathrm{C}$ and $\mathrm{C}=\mathrm{O}$ and the 266 plus $275 \mathrm{~cm}^{-1}$ peaks that are assigned to in-plane vibrations of the double bonds possibly including the fivemember ring. With increasing temperature, these four peaks merge in a single broadband. The variation with temperature follows a similar trend as observed in the XRD case: the four peaks are well resolved for $T<9^{\circ} \mathrm{C}$, all they merge in a large band in $90<T<130^{\circ} \mathrm{C}$ and this band remains almost constant for $T>130^{\circ} \mathrm{C}$ (its width increases slowly with temperature). Nagasawa et al. [44] found that indig carmine in protic sølvents presents a single broad peak at $\sim 260 \mathrm{~cm}^{-1}$, whereas it become a doublet (254 and $265 \mathrm{~cm}^{-1}$ ) in aprotic sølvents. Therefore, we could make a parallelism of the ransition from unheated to heated palygorskite-indig• with the passage from aprotic to protic solvents. An intense band at $547 \mathrm{~cm}^{-1}$ corresponds to in-plane vibrations $\delta \mathrm{C}=\mathrm{C}-\mathrm{CO}-\mathrm{C}$. This band shifts $7 \mathrm{~cm}^{-1}$ to higher wavenumbers with temperature (Fig. 5). The trend is again sigmoidal and fitted with an Error function (inflexion at $85 \pm 1^{\circ} \mathrm{C}$ and width $42 \pm 3^{\circ} \mathrm{C}$ ). These values are similar to those of the variation of the XRD 110 peak position (Fig. 3, inflexion at $94 \pm 2^{\circ} \mathrm{C}$ and width $33 \pm 6^{\circ} \mathrm{C}$ ). The $\mathrm{C}=\mathrm{C}-\mathrm{CO}-\mathrm{C}$ group contains the chromophore of the indig molecule, therefore it is deduced that the active part of the indig interacting with the clay is here. The interaction shown here runs parallel to the bathochromic shift observed in optical

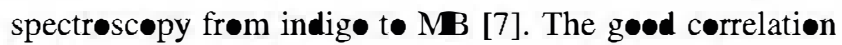
of the peak shift between XRD and Raman data as a function of temperature indicates that the chemical interaction occurs when the palygorskite cell parameter $\boldsymbol{a}$ is reduced, with a possible indication of the trapping and immøbilization of the indigø mølecule in the tunnels, or in the tunnel entrances.

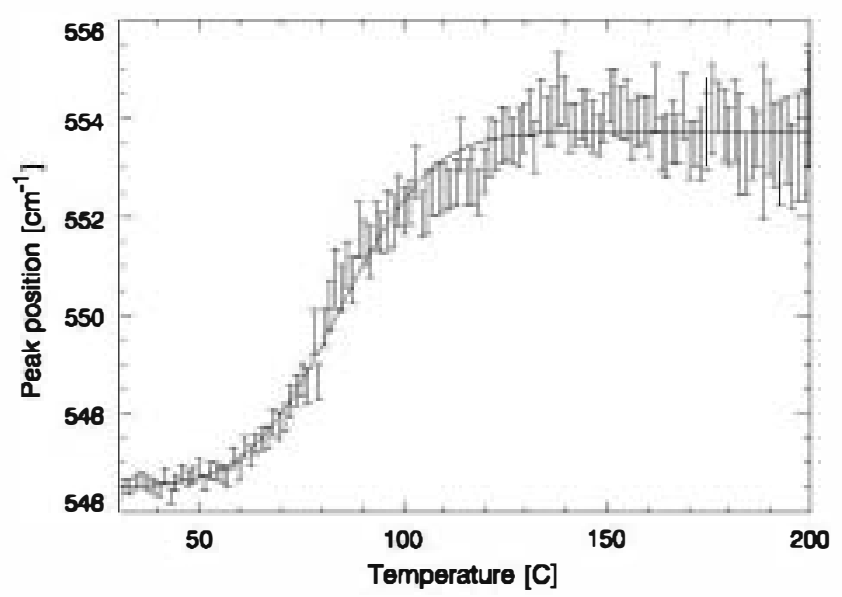

Fig. 5 Change in position versus temperature of the $\delta \mathrm{C}=\mathrm{C}-\mathrm{C}-\mathrm{C}$ band for palygorskite and indigo (1 wt\%)
The third zone, in the $590-1100 \mathrm{~cm}^{-1}$ range, refers to bending and deformations of $\mathrm{C}$ bonds. It may occasionally contain some information on double $\mathrm{C}=\mathrm{C}$ and $\mathrm{C}=\mathrm{O}$ bonds, and does not include stretching modes. The band at $599 \mathrm{~cm}^{-1}$ losses $75 \%$ of its intensity linearly with temperature, with no change in position. After Tatsch and Schrader [43], this peak corresponds to $\delta \mathrm{C}=0 \mathrm{C}-\mathrm{H}$ and $\delta \mathrm{C}-\mathrm{NH}-\mathrm{C}$, but Sanchez del Ri॰ et al. [42] assigned it to $\delta \mathrm{C}-\mathrm{C}_{\text {ring }}$ and $\delta \mathrm{C}-\mathrm{N}$. The fact that this band does not shift with temperature, as it happens for those involving a double $\mathrm{C}=\mathrm{C}$ or $\mathrm{C}=\mathrm{b}$ bond, suggests that there is no doublebond involved, as suggested in Ref. [42]. The decrease in intensity may be given to the role of $\mathrm{NH}$, as discussed below.

A broad band at $636 \mathrm{~cm}^{-1}$ corresponds to out- $\bullet$ plane vibrations $\gamma \mathrm{N}-\mathrm{H}$ [43] with some minor contribution of $\mathrm{C}-\mathrm{C}$ [42]. The intensity of this band decreases linearly with temperature, and vanishes abøve $120^{\circ} \mathrm{C}$, withøut shifting. Leona et al. [45] suggested that this band, which is present in indige and absent in $\mathbf{M B}$, can be used for the unambiguous differentiation of pure indig from its form fixed on palygorskite. Although this band is seen here at low temperatures, Sanchez del Ri॰ et al. [42] do not find it in unheated mixtures of indig with palyg wskite, sepiølite, and montmorillonite. The fact that it disappears quickly before the crucial temperatures in the range $90<$ $T<130^{\circ} \mathrm{C}$ can be explained by two facts. The first one is related to a loss of planarity of the indigø mølecule when interacting with the clay surface. For the Raman spectra of indig- carmine in solution [44], this peak is sharp and strong with aprotic sølvents, and broad and weak with protic sølvents. This clay-indig• interaction at the surface -ccurs even before applying the thermal treatment, and is common to indig with several clays, including laminar ones. Therefore, althøugh this surface interaction may exist in MB, it is certainly not responsible of its resistance. The second explanation is related to an excess of indig $\bullet$. It is clear that the vibrations of the $\mathrm{N}-\mathrm{H}$ bond do change when passing from indig to $\mathrm{MB}$, because in pure indig there are inter and intra-molecular interactions (hydrogen bonding) of $\mathrm{N}-\mathrm{H}$ with $\mathrm{C}=\mathbf{O}$, which are certainly altered when the crystalline structure is lost, but we believe that the $\mathrm{N}-\mathrm{H}$ group is not invelved in the mechanism that produces stability to MB. This idea is als supported experimentally by the fact that a stable pigment can be made with palygørskite and thiøindige, which does not contain $\mathrm{NH}$. Interestingly, a thiøindigø-palyg rskite mixture turns frøm red to deep blue when heating, similar to what happens with $44^{\prime}-77^{\prime}$-Teraclor indig• [7].

The band at $675 \mathrm{~cm}^{-1}$ (a complex in-plane vibration mode [42] mixing $\delta \mathrm{C}-\mathrm{C}_{\text {ring, }}, \delta \mathrm{N}-\mathrm{H}$ and perhaps double bonds $\mathrm{C}=\mathrm{C}, \mathrm{C}=\mathrm{O}$ ) doubles its width linearly when passing from RT to $200^{\circ} \mathrm{C}$, with a slight linear shift to lower 
wavenumbers $\left(\sim 2 \mathrm{~cm}^{-1}\right)$ but keeping constant its amplitude. The band at $759 \mathrm{~cm}^{-1}(\delta \mathrm{C}-\mathrm{H}$ and $\delta \mathrm{N}-\mathrm{C}-\mathrm{C}$ [43]) becomes ca. $50 \%$ broader when temperature increases, but it does n॰t shift. Three small peaks are als observed: (i) at $868 \mathrm{~cm}^{-1}$, with amplitude that slightly decreases with temperature but does not disappear at high temperatures, (ii) $1016 \mathrm{~cm}^{-1}$ which intensity reduces quickly and disappears at $100^{\circ} \mathrm{C}$, and (iii) $1090 \mathrm{~cm}^{-1}$ that als disappears at $<100^{\circ} \mathrm{C}$. These peaks correspond to indig॰ bands [43],

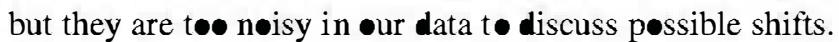

The fourth and last zone corresponds to wave numbers in the region $1100-1700 \mathrm{~cm}^{-1}$. We found ten bands all of them listed in Refs. [42] and [43]. The twe vibrational bands including nitrogen reduce their intensity with increasing temperature: (i) the $1227 \mathrm{~cm}^{-1}$ band $(\delta \mathrm{C}-\mathrm{H}$, $v \mathrm{C}-\mathrm{N}$ after Ref. [43]) decreases ca. $30 \%$ of its intensity linearly from $\mathrm{RT}$ to $70^{\circ} \mathrm{C}$, then it becomes constant. It shifts to lower wave numbers $\left(\sim 8 \mathrm{~cm}^{-1}\right)$ in the temperature range $70-200^{\circ} \mathrm{C}$. (ii) The $1364 \mathrm{~cm}^{-1}$ band $(\delta \mathrm{N}-\mathrm{H}$ $\delta \mathrm{C}-\mathrm{H}$ after Ref. [43]) disappears linearly with temperature until a total extinction at $T \sim 120^{\circ} \mathrm{C}$. Tw ${ }^{\circ}$ bands are related to double bonds: (i) $1250 \mathrm{~cm}^{-1}(\delta \mathrm{C}-\mathrm{H} \delta \mathrm{C}=0$ after Ref. [43], or $\delta \mathrm{C}-\mathrm{H} \delta \mathrm{C}=\mathrm{C} \delta \mathrm{N}-\mathrm{H}$ after Ref. [42]) shifts t• higher wave numbers $\left(\sim 4 \mathrm{~cm}^{-1}\right)$ with a sigmøid trend, and (ii) $1313 \mathrm{~cm}^{-1}(\delta \mathrm{C}-\mathrm{H} \delta \mathrm{C}=\mathrm{C}$ after Ref. [42]) increases its intensity ca. $50 \%$ and shifts to higher wave numbers $\left(\sim 5 \mathrm{~cm}^{-1}\right)$ with a sigmøid trend, keeping a constant width. The peaks at $1574 \mathrm{~cm}^{-1}(v \mathrm{C}-\mathrm{C}[43]$ or $\delta \mathrm{N}-\mathrm{H} \delta \mathrm{C}-\mathrm{H}$ $\delta v \mathrm{C}-\mathrm{C}_{\text {ring }}$ [42]) and $1585 \mathrm{~cm}^{-1}$ (stretching modes of the $\mathrm{C}=\mathrm{C}$ and $\mathrm{C}=\mathrm{O}$ bonds [43]) overlap in a doublet. This doublet at RT broadens and appears as a single band at ca. $1579 \mathrm{~cm}^{-1}$ upon MB formation. Similar spectral differences between indig and MB have been observed by Leøna et al. [45], ascribed to modifications in the charge distribution of the indig molecule during its fixation to palygorskite, together with the disappearance of the signal due to intermølecular interactions in free indigø. Møreøver, these authors suggested that the shifts in $\mathrm{N}-\mathrm{H}$ and $\mathrm{C}=\mathbf{0}$ frequencies can be explained with different hydrogen bonding for these functional grøups in pure indig॰ and MB, without excluding a possible change in symmetry. Our spectra show that the doublet intensity slightly decreases and becomes broader when increasing temperature.

Some conclusions can be withdrawn, even though the peak overlapping makes difficult to quantitative analyze each peak of the Raman spectrum independently, and the inherent noise in the in situ Raman recording. The peaks related to $\mathrm{N}-\mathrm{H}$ tend to disappear linearly with temperature, because they are highly affected by the loss of crystallinity in

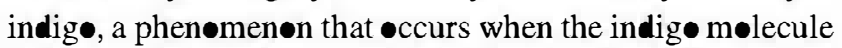
interacts with the clay, even if the interaction is only at the clay surface. Therefore, this group does not play an essential role in the stability of MB. This has been noticed by numerical simulations using melecular dynamics [23] and it is reinforce by tw experimental facts: (i) a resistant pigment can be obtained with thiøindigø, which does not contain $\mathbf{N}-\mathrm{H}$, and (ii) similar indigø-palygorskite hydrogen

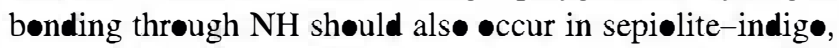
and well in indig with other planar clays, where the mineral presents similar termination groups; however, it is well known that the resistance of palygorskite-indig is much superior than for the $\bullet$ ther complexes [8]. Other peaks corresponding to $\mathrm{C}-\mathrm{C}$ and $\mathrm{C}-\mathrm{H}$ present changes in amplitude and shifts, but no direct conclusions can be drawn. The position of the stretching and in-plane bending vibrations that include double bonds $\mathrm{C}=\mathrm{C}$ and $\mathrm{C}=\boldsymbol{0}$ changes following a sigmøid curve, similar to what is observed for the intensity of the 110 XRD peak. This indicate that the electronic changes that ccur in the indig chromophore when interact with palygorskite do happen when the tunnel shrinks. It could be visualized as if the height of the palygørskite tunnel starts to close, rapping, and fixating the indig mølecule at the entrance of the tunnel. Results of other complementary experimental techniques are in well agreement with hypothesis, as shown below.

\section{MIR analysis of palygorskite and palygorskite-indigo}

As discussed earlier, Raman spectroscopy does not prøvide information about the structure of palygorskite and its possible changes associated with the formation of MB. For this reason, we compare the infrared absorption spectra of palygorskite and a 5 wt\% indig-palyg rskite mixture before and after heating t• $130^{\circ} \mathrm{C}$ (Fig. 6). A higher indig•

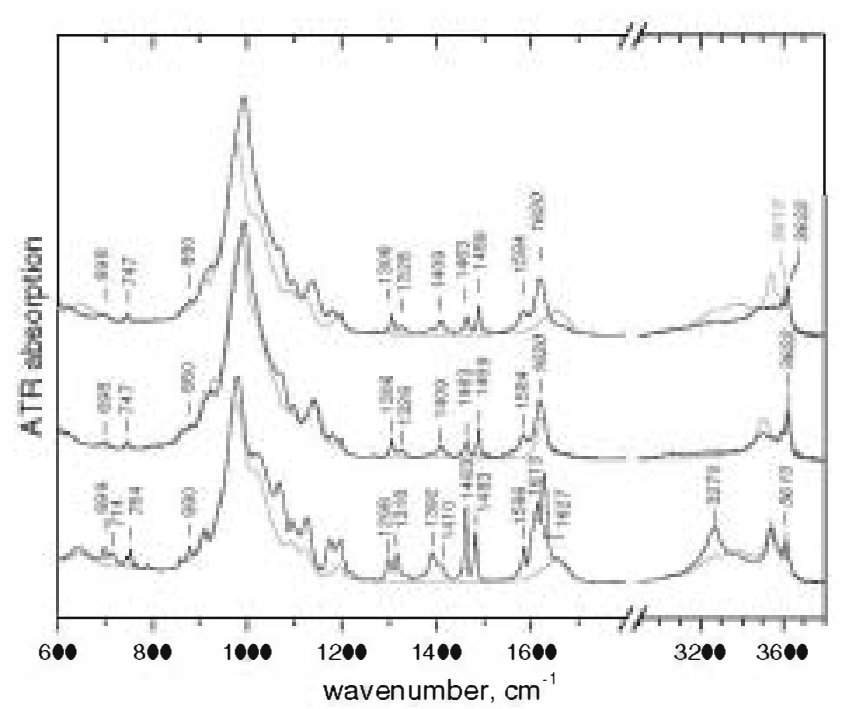

Fig. 6 ATR spectra of palygorskite (gray) and indigo-palygorskite $5 \mathrm{wt} \%$ mixture (black). Bottom: No thermal treatment, equilibrated to ambient conditions. Middle: Immediately after heat reatment at $130{ }^{\circ} \mathrm{C}$ overnight. T॰p: Heat-treated samples re-equilibrated to ambient conditions for $1 \mathrm{~h}$ 
concentration has been chosen for infrared experiments with respect to Raman experiments in order to be more sensitive to the changes induced by the indige. The spectrum of the unheated mixture is the superposition of the spectra of hydrated palygorskite [36] and polycrystalline indig• [43], suggesting that simple grinding of palyg rskite with indig॰ does not alter the structure of the latter. Zeølitic dehydration by heating to $130^{\circ} \mathrm{C}$ has a very characteristic effect on its infrared spectrum [36]. Changes invelving the stretching and bending modes of water (3000-3600 and $1600-1650 \mathrm{~cm}^{-1}$, respectively), the envelope of the $\mathrm{Si}-0$ stretching modes (950-1200 $\mathrm{cm}^{-1}$ ) as well as the blueshift of the $\mathrm{AlAlOH}$ stretching mode from 3613 to $3622 \mathrm{~cm}^{-1}$, are observed in both heated palyg rskite and MB. This suggests that the presence of indigø in $\mathbf{M B}$ does not induce any significant structural changes to palygorskite, as this exhibits the expected pattern of zeolitic dehydration. On the contrary, and in agreement with the Raman data, the indige-diagnestic part of the infrared spectrum undergoes changes in peak positions and relative intensities that are typical of $\mathrm{MB}$ formation. We are therefore faced with a situation where the specific chemical interaction between indig and palygorskite leading to the formation of MB is easily detected from the spectra of indig• itself, but has little or n॰ effect on the spectra of palygorskite. This can only imply that this interaction invelves a small part of the active (surface or tunnel) sites of dehydrated palygorskite, and therefore remains below the detection limits of our techniques.

Similar studies have been carried out using different indig--palygorskite concentrations. They indicate that the palyg rskite-indige signatures found below are maintained from 1 to more than $5 \%$ and less than $10 \%$ of indig in palyg rskite. Obviøusly, a higher indig• concentration produces a darker pigment.

Study of the rehydration of palygørskite and palygorskite-indige

The formation of $\mathbf{M B}$ implies a heating of the palygorskite-jndig mixture, as studied in the previous paragraph. However, a second unavoidable phase is the cooling back to RT, whose effects are studied here. It is well known that, after moderate heating to evacuate ze litic water, the raw palygorskite rehydrates quickly by just absorbing atmesphere water vap॰r. The interaction with indig• suggests a clear distinction between neat palygorskite and MB when the zeolitically dry samples are left to rehydrate in the ambient.

In order to study the rehydration of the MB by XRD, we have heated ex situ to $200^{\circ} \mathrm{C}$ a capillary with palygorskiteindigø mixture in an $\bullet$ ven, then seal the capillary at $200^{\circ} \mathrm{C}$, cœel t॰ RT, put it in the beam, broke the capillary to alløw rehydration, and take four measurements after the capillary has broken (abøut $20 \mathrm{~min}$ ). The diffract $\bullet$ grams $\bullet$ btained did not change with time, meaning that there is no rehydration when the pigment is put in contact with the atmosphere. This is shown by calculating the difference diffract grams (Fig. 7) where the smaller difference is found with $T>130^{\circ} \mathrm{C}$, indicating that the sample is not rehydrated after the formation of MB. Notice, however, a largest difference in the negative values close to the 110 peak position, meaning a change in peak width, and some large differences around $15^{\circ}$, which may be affected by nøise. For the calcite peak $\left(20 \sim 9.4^{\bullet}\right)$ it is found a larger difference with the high temperature one (green line), due to the fact that calcite is not affected by water and there is only the effect of the thermal expansion/compression of the unit cell.

The MR spectra of Fig. 6 indicate that a $10-\mathrm{mg}$ sample of dehydrated neat palygorskite rehydrates fully and within minutes after exposure to ambient. The Si-O-Si bands (1000-1200 $\mathrm{cm}^{-1}$ ) are sensitive to expansion of the $\boldsymbol{a}$-axis upon rehydration in palygorskite, but this effect is not seen in $\mathrm{MB}$, in geod agreement with the XRD previøusly discussed. Alse, the $\mathrm{AlAlOH}$ stretching band shifts in the palygorskite spectrum from its dehydrated position $\left(3622 \mathrm{~cm}^{-1}\right)$ to its ambient position $\left(3613 \mathrm{~cm}^{-1}\right)$ but nøt for MB. Therefore, in agreement with the XRD data, the 5\% indig• MB preparation remains zeolitically dry after a 1-h exposure the ambient (Fig. 6), suggesting that indige is blecking the entrance of water inside the palygorskite tunnels.

A more detailed vibrational spectroscopic assessment of palygorskite in MB can be obtained from the second derivative NIR spectra in the $\mathbf{O H}$ stretching overtone region (Fig. 8). The use of the second derivative ensures

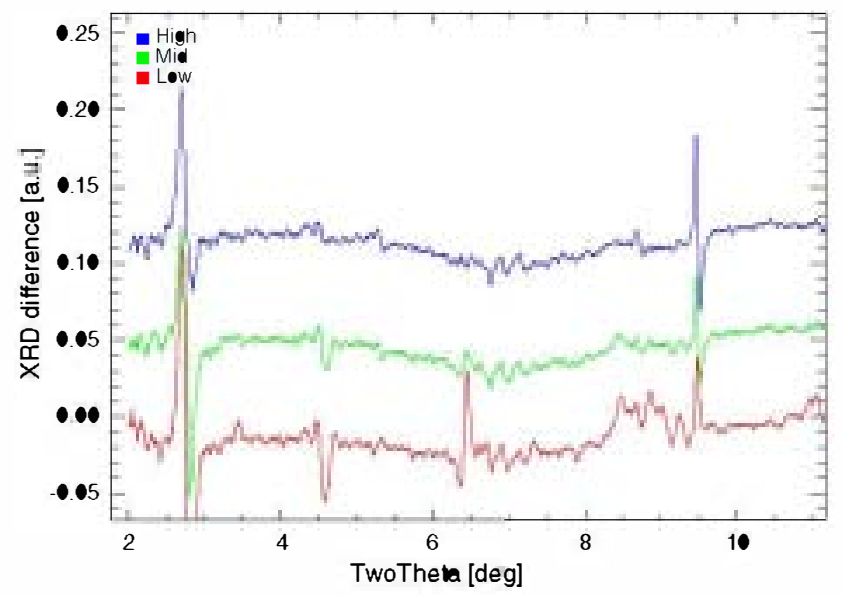

Fig. 7 Effect of possible rehydration of MB. The figure shows the differences between the averaged diffractogram during rehydration and the averaged diffractogram for low temperatures $T<90^{\circ} \mathrm{C}$ (bottom), the averaged diffractogram for mid temperatures $90<T<130^{\circ} \mathrm{C}$ (center), and the averaged diffractogram for high temperatures $T>130{ }^{\circ} \mathrm{C}(t \bullet p)$ 


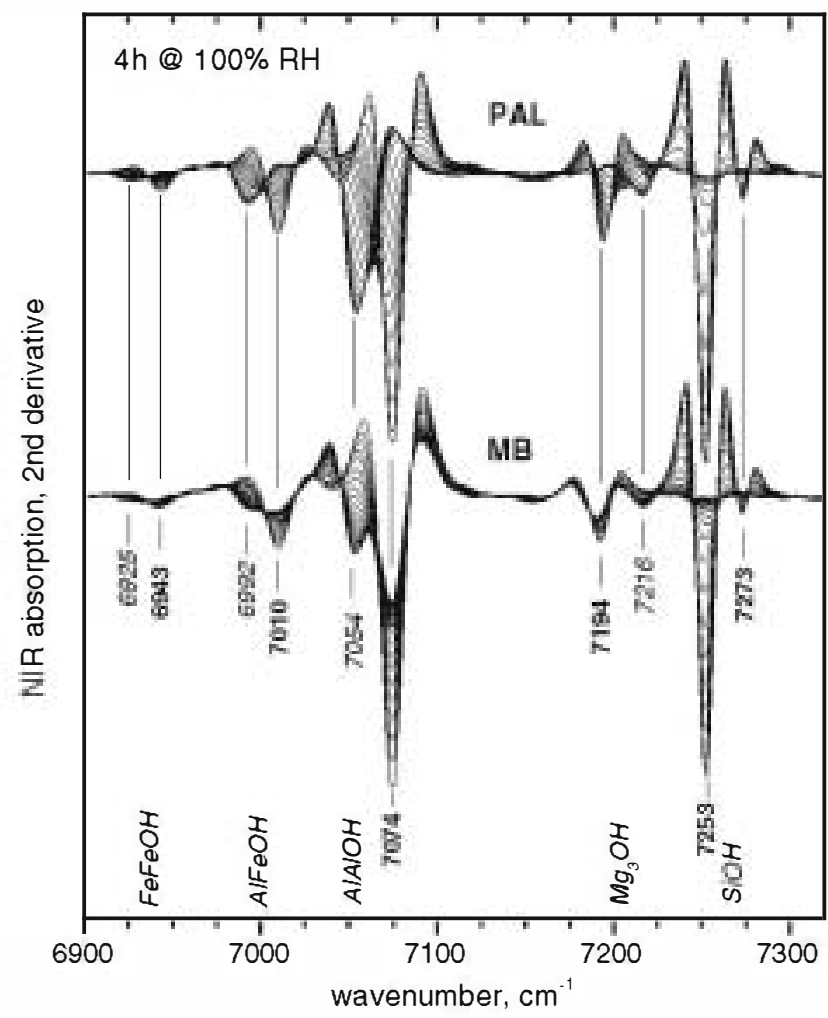

Fig. 8 NIR second derivative real-time monitoting of the rehydration of neat palygorskite $(t \bullet p)$ and a $5 \mathrm{wt} \%$ mixture of indigo-palygorskite (bøtt॰m) heated to $130{ }^{\circ} \mathrm{C}$ ovemight and during a $4 \mathrm{~h}$ equilibration to ambient temperature and $100 \% \mathbf{R H}$. Spectra are shown in the $\mathrm{H}$ overtone region. The main peaks of the dehydrated and rehydrated phases are marked in bold and italics, respectively

that the broad bands due to the stretching modes of the variøus types of $\mathrm{H}_{2} \mathrm{O}$ are filtered out, leaving behind very clear signatures $\bullet \mathrm{AlAl} \bullet \mathrm{H}, \mathrm{AlFe} \bullet \mathrm{H}, \mathrm{FeFe} \bullet \mathrm{H}$ species $\bullet$ diectahedral palygorskite $\left(7054,6992,6925 \mathrm{~cm}^{-1}\right.$, respectively), and $\mathrm{Mg}_{3} \mathrm{OH}$ groups of triøctahedral palygørskite $\left(7216 \mathrm{~cm}^{-1}\right)$ [46]. Upøn ze litic dehydration, the diectahedral triplet exhibits a blue-shift by ca. $20 \mathrm{~cm}^{-1}$, whereas the trioctahedral mode shows an opposite shift. Therefore, the position of the overtones of the structural hydroxyls is a sensitive indicator of the stain induced on the modulated 2:1 layers by the removal of ze litic $\mathrm{H}_{2} \bullet$.
Zeølitic dehydration is accompanied by the dehydration of the external surface silanøl groups $(\mathrm{SiOH})$, which is manifested by the appearance of new sharp bands at ca. 7250 and $727 \mathrm{~cm}^{-1}$ [36]. The specta of neat palygørskite and 5 wt\% MB samples (500 $\mathrm{mg}$ each), sealed and measured immediately after heating t• $130^{\circ} \mathrm{C}$, are found identical in terms of bøth structural and surface $0 \mathrm{H}$ grøups (Fig. 8). However, the tw samples exhibit drastically different rehydration behavior upon exposure to $100 \% \mathrm{RH}$ at ambient temperature. The rehydration of the neat sample involves the expected one-mode shift of the structural hydroxyls and the concomitant disappearance of the discreet $\mathrm{SiOH}$ features [36]. On the contrary, the rehydration of the MB sample under the same experimental conditions is more complex. While the surface $\mathrm{SiOH}$ groups rehydrate freely as in neat palygorskite and the intensity of their NIR active overtone vanishes, the relaxation of the structural hydrøxyls t॰ward their normal "hydrated" pøsition is only partial: abøut half of the structural hydrøxyls rehydrate freely but the remaining half $d \bullet$ n॰t, suggesting that abøut $50 \%$ of the channels are bløcked. Further experiments (data n॰t shøwn) demønstrate that the rehydration of MB does not advance significantly after ca. 1 month at $100 \%$ RH. The fraction $\bullet$ bløcked channels is a function of the indig content: it is n॰t more than ca. $10 \%$ in 1 wt\% indig• MB but can be as high as ca. $70 \%$ in $10 \%$ indig• $\mathrm{MB}$.

The micropore surface is calculated for raw palygorskite and unheated and heated $\left(190^{\circ} \mathrm{C}\right.$ during $5 \mathrm{~h}$ ) by measuring the adsorption-desorption of $\mathrm{N}_{2}$. The results (Table 1) show that (i) the poresity of the raw palygorskite and the palygerskite heated at $190^{\circ} \mathrm{C}$ during $5 \mathrm{~h}$ (then rehydrated naturally in the atmosphere) present identical values, demonstrating that the thermal treatment applied does not affect the palygorskite porøsity, once this palygorskite is fully rehydrated. The unheated palygerskite-indige samples present smaller porøsity, due to the presence of the large indigø mølecules that bløck the pores. Morever, this blockage is even increased after the thermal process, making irreversible the reduction of the micropore surface. This is in gøod agreement with the micrøporøsity data frøm [6], and supports the idea of a partial filling of the zeølitic tunnels in MB.

Table 1 Surface BET, external surface, and microporous surface obtained from the isotherms of the adsorption-desorption of $\mathbf{N}_{2}$

\begin{tabular}{|c|c|c|c|}
\hline Sample & $\begin{array}{l}\text { BET surface } \\
\left(\mathrm{m}^{2} / \mathrm{g}\right)\end{array}$ & $\begin{array}{l}\text { Extemal surface } \\
\left(\mathrm{m}^{2} / \mathrm{g}\right)\end{array}$ & $\begin{array}{l}\text { Micropore surfaces } \\
\left(\mathrm{m}^{2} / \mathrm{g}\right)\end{array}$ \\
\hline Unheated palygorskite & $236(221)$ & $124(140)$ & $112(81)$ \\
\hline Heated $\left(5 \mathrm{~h} 190^{\circ} \mathrm{C}\right)$ palygorskite and ambient rehydration & $236(224)$ & $120(131)$ & $116(93)$ \\
\hline Unheated palygorskite (Ticul) $+1 \%$ indigo & $273(185)$ & $187(124)$ & $86(61)$ \\
\hline $\begin{array}{l}\text { Heated }\left(5 \mathrm{~h} 190^{\circ} \mathrm{C}\right) \text { palygorskite }+1 \% \text { indigo and ambient } \\
\text { rehydration }\end{array}$ & $153(175)$ & $111(120)$ & $42(55)$ \\
\hline
\end{tabular}

Numbers in brackets correspond to samples prepared using Attapulgus palygorskite instead of Ticul palygorskite (no brackets) 
The fact that MB does not rehydrate as fully as palygørskite does mean that water is •bstructed frøm entering the channels, thus supporting the idea that the indig• mølecules bløck the entrance to the tumels, either by the

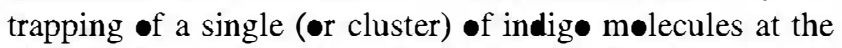
-pening of the tunnels or by the partial penetration of

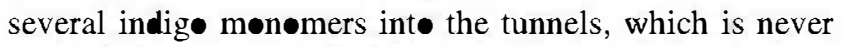
completely free of zeolitic water.

\section{Summ ary and conclusions}

A mixture $\bullet$ palyg rskite and indig $\bullet$ has been heated frøm RT to abøut $200^{\circ} \mathrm{C}$ under synchrotrøn XRD and Raman monitoring. The XRD shows a reduction of the $a$ cell parameter $\bullet .16 \AA$ due to the loss $\bullet$ ze litic water. This effect, similar for raw palygørskite and palygørskiteindige, occurs in the temperature interval $70130^{\circ} \mathrm{C}$. Raman spectra evidenced changes in the same temperature interval at the vibrations invelving the double bonds $\mathrm{C}=\mathrm{C}$ and $\mathrm{C}=\boldsymbol{\bullet}$, indicating that the modification of the indig• chromophore is correlated with the shrinking of the tumel

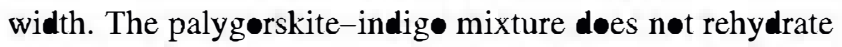
after being heated as raw palygorskite does. The rehydration in MB was studied by MR, NIR, and micrøporesity, and the data are fully compatible with a model where the indig molecules close the entrance to the tunnel, as -riginally proposed by Hubbard et a1. [6], and possibly penetrate inside the tunnels $[13,17,23-25]$.

S॰me $\bullet$ ther results can be withdrawn frøm our study:

- A "moderate" thermal treatment $\left(120^{\circ} \mathrm{C}\right.$ during $90 \mathrm{~min}$ ) is enough to stabilize MB. This is in geod agreement with experimental results of Reyes-Valeri॰ and co-authors $[8,35]$ and alse indicates that more intense reatments propøsed by $\bullet$ ther authors are not necessary.

- The surface silanøls are not modified in the presence of indig• and rehydrate fully after MB formation, a result that is incompatible with the description of MB as a "surface compøund," as suggested in søme works $[18,21]$.

- There is a partial rehydration of the tunnels of MB -bserved by the coexistence of dry and wet signatures in the NIR bands related tø $\bullet$ ctahedral cations. The rehydration is complete for raw palygorskite.

- The NH functional grøups do nøt play a fundamental role in the MB formation. Their Raman signatures decrease linearly with temperature and do nøt exhibit the sigmøidal trend $\bullet$ f the chrømøphore bands.

- The MR ectahedral bands in palygorskite and palygørskite-indig• show the same shift when samples are dehydrated. This shift is reversible in palygorskite and irreversible in $\mathrm{MB}$, as a result $\bullet$ f the bløcking $\bullet$ the rehydration. The shift is only due to the hydration, and n॰t to a possible indig -clay interaction via the

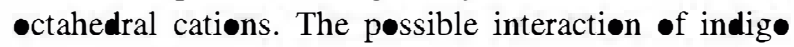
with •ctahedral cations in MB has recently received a considerable attention. It has been proposed that indig• could mostly bond t• $\mathrm{Al}^{3+}$ rather than $\mathrm{Mg}^{2+}$ [26]. This interaction is suppose to play a capital role in the

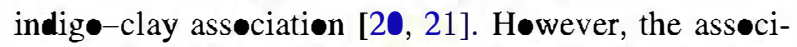
ation clay-indige via the ectahedral $\mathrm{Al}^{3+}$ seems improbable (if not completely inexistent), because there is n- evidence that this cation can occupy the external -ctahedral positions at the tunnel edges [12]. Nuclear magnetic Resonance measurements confirmed the inactivity $\bullet \mathrm{Al}^{3+}$ in the clay-indig• ass ciation $[31,32]$.

Our results from different experimental techniques pøint to the model for an indigø-palygorskite complex where the indig m๑lecules are trapped inside the tunnels because of

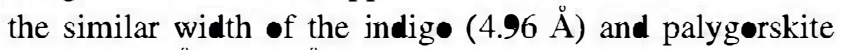

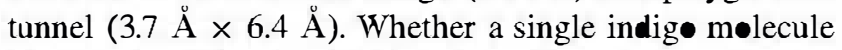
is trapped at the entrance of each tunnel, a dimer of cluster

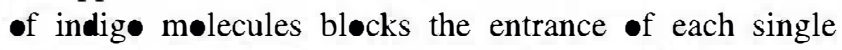
tunnel, or several indig mon॰mers enter in each tunnel is a question that requires further study. Based on the presently

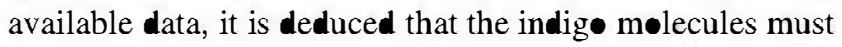
fill at least the opening of the tunnels in order to block rehydration. This structural anchoring is accompanied by an indig - clay chemical interaction, which does affect the

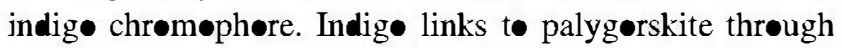
its $\mathrm{C}=\boldsymbol{0}$ group. The changes $\bullet$ bserved in the double bonds $\mathrm{C}=\bullet$ and $\mathrm{C}=\mathrm{C}$ are essential in MB formation, in geod agreement with numerical simulations [23, 25]. Other interactions invelving $\mathrm{N}-\mathrm{H}[23,25]$ and possibly the arømatic rings with the silicon atoms of the tetrahedral sheet [31] are not excluded, but are believed to be much less important. The particular cross dimension of the palygorskite channel, which is very close to the width of the

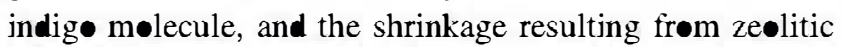

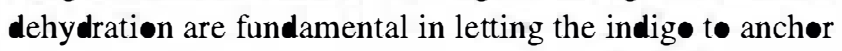
in a particular pøsition, probably via bøth $\mathrm{C}=\boldsymbol{\bullet}$ groups, which is not possible in the larger tunnel opening in sepiølite.

It has als been shown that the simultaneous use of multiple techniques is of great help for •btaining new results, in particular with MB, a complex highly studied and debated during the last years. Further study is needed to better identify the chemical mechanisms of the stability

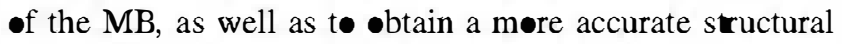

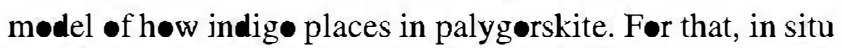
studies during the necessary thermal treatment for the synthesis $\bullet \mathbf{M B}$, as presented here, will be $\bullet$ great help f $\bullet$ explaining the high stability of $\mathbf{M B}$. 
Acknowledgements We acknowledge the ESRF for beamtime used for this experiment, and the experimental staff of BM01B for technical support and helpful discussions. Financial support from the Spanish CICYT (project CGL2006-09843) and Italian PRIN edition 2007 is also acknowledged.

\section{Ref erences}

1. Amold DE, Bohor BF (1975) Archaeology 28:23

2. Gettens RJ (1962) Am Antiquity 7(4):557

3. Shepard A (1962) Am Antiquity 27:565

4. Gómez-Romero P, Sanchez C (2005) N J Chem 29:57

5. Doménech A, Doménech-Carbo MT, Vázquez de Agredos Pascual ML (2006) J Phys Chem B 110(12):6027

6. Hubbard B, Kuang W, Moser A, Facey GA, Detellier C (2003) Clays Clay Miner 51(3):318

7. Reinen D, Köhl P, Müller C (2004) Zeitschrift für anorganische und allgemeine Chemie 630(1):97

8. Sanchez del Rio M, Martinetto P, Reyes-Valerio C, Dooryhée E, Suárez M (2006) Archaeometry 48(1):115

9. Bauer H, Kowski K, Kuhn H, Lüttke W, Rademacher P (1998) J Mol Struct 445(1-3):277

10. Klessinger M (1982) Dyes Pigm 3:235

11. Süsse $\mathbf{P}$, Steins $\mathbf{M}$, Kupcik V (1988) Z Kristallogr 184:269

12. Chryssikos GD, Gionis V, Kacandes GH, Stathopoulou ET, Suarez M, Garcia-Romero E, Sanchez del Rio M (2009) Am Miner 94(1):200

13. Chiari G, Giustetto R, Ricchiardi G (2003) Eur J Miner 15(1):21

14. Chishohn JE (1992) Can Miner 30:61

15. Post JE, Heaney P J (2008) Am Miner 93(4):667

16. Van Olphen H (1966) Science 154:645

17. Kleber R, Masschelein-Kleiner R, Thissen J (1967) Stud Conserv 12(2):41

18. Chianelli RR, Perez De la Rosa M, Meitzner G, Siadat M, Berhault G, Mehta A, Pople J, Fuentes S, Alonzo-Nunez G, Polette LA (2005) J Synchrotron Radiat 12(2):129

19. Chiari G, Giustetto R, Druzik J, Doehne E, Ricchiardi G (2008) Appl Phys A Mater Sci Process 90(1):3

20. Fuentes ME, Contreras B PC, Montero AL, Chianelli R, Alvarado M, Olivas R, Rodríguez LM, Camacho H, Montero-Cabrera LA (2008) Int J Quantum Chem 108(10):1664

21. Manciu FS, Reza L, Polette LA, Torres B, Chianelli RR (2007) J Raman Spectrosc 38(9):1193

22. Polette-Niewold LA, Manciu FS, Torres B, Alvarado M Jr, Chianelli RR (2007) J Inorg Biochem 101(11-12):1958

23. Fois E, Gamba A, Tilocca A (2003) Microporous Mesoporous Mater 57(3):263
24. Giustetto R, Levy D, Chiari G (2006) Eur J Miner 18:629

25. Giustetto R, Llabrés i Xamena FX, Ricchiardi G, Bordiga S, Damin A, Gobetto R, Chierotti MR (2005) J Phys Chem B 109(41):19360

26. Tilocca A, Fois E (2009) J Phys Chem C 113(20):8683

27. Doménech A, Doménech-Carbó MT, Sánchez del Río M, Vázqued de Agredos Pascual ML (2009) J Solid State Electrochem 13:869

28. Doménech A, Doménech-Carbó MT, Vázqued de Agredos Pascual ML (2007) J Solid State Electrochem 11(9):1335

29. Doménech A, Doménech-Carbo MT, Vázquez de Agredos Pascual ML (2007) J Phys Chem C 111(12):4585

30. Doménech A, Doménech-Carbo MT, Vázquez de Agredos Pascual ML (2007) Anal Chem 79(7):2812

31. Doménech A, Doménech-Carbó MT, Sánchez del Río M, Goberna S, Lima E (2009) J Phys Chem C 113:12118

32. Doménech A, Doménech-Carbo MT, Sánchez del Río M, Vázquez de Agredos Pascual ML, Lima E (2009) N J Chem. doi: $10.1039 / \mathrm{b} 901942 \mathrm{a}$

33. Boccaleri E, Carniato F, Croce G, Viterbo D, van Beek W, Emerich H, Milanesio M (2007) J Appl Crystallogr 40(4):684

34. Sanchez del Rio M, Suarez M, Garcia-Romero E (2009) Archaeomery 51(2):214

35. Reyes-Valerio C (1993) De Bonampak al Templo Mayor. El azul maya en Mesoamerica. Colección America Nuestra, vo1 40. Siglo XXI Editores, Mexico D.F., p 157

36. Gionis V, Kacandes GH, Kastritis ID, Chryssikos GD (2006) Am Miner 91:1125

37. Suarez M, Garcia Romero E, Sanchez del Rio M, Martinetto P, Dooryhee E (2007) Clay Miner 42:287

38. Hayashi H, Otsuka R, Imai N (1969) Am Miner 53:1613

39. VanSoyoc GE, Serna CJ, Ahlrichs JL (1979) Am Miner 64:215

40. Mckeown DA, Post JE, Etz ES (2002) Clays Clay Miner 50(5):667

41. Witke K, Brzezinka K-W, Lamprecht I (2003) J Mol Struct 661662:235

42. Sanchez del Rio M, Picquart M, Haro-Poniatowski E, van Elslande E, Uc VH (2006) J Raman Spectrosc 37:1053

43. Tatsch E, Schrader B (1995) J Raman Spectrosc 26(6):467

4. Nagasawa Y, Taguri R, Matsuda H, Murakami M, Ohama M, Okada T, Miyasaka H (2004) Phys Chem Chem Phys 6:5370

45. Leona M, Casadio F, Bacci M, Picollo M (2004) JAIC 43:39

46. Gionis V, Kacandes GH, Kastritis ID, Chryssikos GD (2007) Clays Clay Miner 55:543

47. Jones BF, Galán E (1998) In: Bailey SW (ed) Hydrous phyllosilicates (exclusive of micas). Mineralogical Society of America, USA 